\title{
Cultural learning that empowers the role of women
}

\section{Aprendizajes culturales que empoderan el rol de las mujeres}

\author{
SALINAS-AGUIRRE, María del Consuelo†*, HERNÁNDEZ-CUETO, Jaquelina Lizet, YÁÑEZ- \\ FLORES, Sara Margarita and EMILIANO-CASTILLO, Carlos Daniel
}

Universidad Autónoma de Coahuila, Postgraduate Department of the Faculty of Science, Education and Humanities, Building "N" Campus Saltillo, Saltillo Coahuila, Mexico.

ID $1^{\text {st }}$ Author: María del Consuelo, Salinas-Aguirre / ORC ID: 0000-0002-6542-1813, Researcher ID Thomson: S92442018, CVU CONACYT ID: 615635

$1^{\text {st }}$ Co-author: Jaquelina Lizet, Hernández-Cueto / ORC ID: 0000-0002-3728-7434, Researcher ID Thomson: S-85882018, CVU CONACYT ID: 322702

$2^{\text {nd }}$ Co-author: Sara Margarita, Yáñez-Flores / ORC ID: 0000-0002-4750-4244, Researcher ID Thomson: S-92312018, CVU CONACYT ID: 352125

$3^{\text {rd }}$ Co-author: Carlos Daniel, Emiliano-Castillo / CVU CONACYT ID: 1095096

DOI: $10.35429 / J M P C .2020 .17 .6 .41 .46$

Received January 25, 2020; Accepted June 30, 2020

\begin{abstract}
It is intended to find learned cultural characteristics, related to genders, susceptible to transform learning for labor equity. By promoting equitable conditions at work, equitable gender participation is promoted in the automotive production sector, a job niche occupied by men. A verification instrument is applied for a descriptive qualitative research with the non-experimental method of interviews with five experts from the productive sector, to investigate on active workers in companies in the automotive sector. The results show different topics of gender learning such as: the behavior of women in jobs that were exclusive to men, investigating the relationships between power and authority regarding gender roles, skills and behavior patterns; mixed work teams; gender role learning: practical advice to be competitive; empower in informal education; strategies for the change of paradigms to obtain labor and political power; attributes of learned roles; differences between power and authority and leadership attributes to empower women, in equality with men. The verification instrument includes types of power, to identify informal keys to empowering women in the labor market and thus access decision-making positions.
\end{abstract}

Informal, Learning, Empowerment, Genders

\begin{abstract}
Resumen
Se pretende encontrar características aprendidas culturales, relacionadas con los géneros, susceptibles a transformar aprendizajes para la equidad laboral. Al propiciar condiciones equitativas en el trabajo, se impulsa la participación equitativa de género en en el sector productivo automotriz, nicho de trabajo ocupado por varones. Se aplica un instrumento de verificación para una investigación cualitativa descriptiva con el método no experimental de entrevistas a cinco expertos del sector productivo, para investigar sobre las trabajadoras en activo en empresas del sector automotriz. Los resultados muestran diferentes tópicos de aprendizajes de género como: el comportamiento de las mujeres en trabajos que eran exclusivos de hombres, investigar las relaciones entre poder y autoridad respecto a roles de género, habilidades $\mathrm{y}$ patrones de comportamientos; equipos de trabajo mixtos; aprendizajes de roles de género: consejos prácticos para ser competitivas; empoderar en educación informal; estrategias para el cambio de paradigmas para obtener poder laboral y político; atributos de roles aprendidos; diferencias entre poder y autoridad y atributos de liderazgo para empoderar mujeres, en equidad con los varones. El instrumento de verificación incluye tipos de poder, para identificar claves informales de empoderamiento de las mujeres en el mercado laboral para acceder a puestos de toma de decisiones.
\end{abstract}

Aprendizaje informal, Géneros, Empoderamiento

Citation: SALINAS-AGUIRRE, María del Consuelo, HERNÁNDEZ-CUETO, Jaquelina Lizet, YÁÑEZ-FLORES, Sara Margarita and EMILIANO-CASTILLO, Carlos Daniel. Cultural learning that empowers the role of women. Journal of Microfinance Planning and Control. 2020. 6-17:41-46.

\footnotetext{
* Correspondence to the Author (Email: consuelo.salinas@uadec.edu.mx)

$\dagger$ Researcher contributing as first author.
} 


\section{Introduction}

Culture has two meanings, Abbagnano N. Fornero update (2012), an old one that means the formation of man, his improvement and improvement; the current concept is from Kant here, and indicates "the production of a rational being, of the ability to choose his own ends. the product of this training, cultivated, civilized and polished ways of living and thinking that make up civilization", from the Greeks education and training according to the "good arts", in that sense the behaviors learned during the development of formal and informal public education assigned to a gender by tradition according to the place and historical moment that is lived. The issue of gender equity is controversial today and there are numerous studies and research in this regard, but there are really no clear proposals for cultural learning that provide long-term solutions, the paradigms of subordination of women have existed through the history of mankind. Different cultures always have learned roles that give inequalities in family and formal education. In public policies, the sense of equity has advanced, but in high positions it is very little, of 194 countries in the world, only 20 are governed by women, according to the ranking "Women in politics 2020 " of the UN Women with the Union interparliamentary Women Now 26 August 2020.

The Latino business culture, and especially the Mexican culture, has made a great effort to establish equal roles at work, but the reality of the Mexican business culture accepts to position women in managerial positions, but in reality they do not. Milenio publishes on December 20, 2020 that in Mexico only 8\% of companies are run by women.

This research provides informal learning proposals that are immersed in the business culture and in the current community.

The approach to the research problem is to promote the equitable participation of women in the labor market and promote long-term gender equitable conditions at work, as well as to achieve healthy competitiveness in access to job positions and decision-making in the labor market, with cultural learning.
The general objective is to know
strategies and informal practical recommendations, to turn the weaknesses of the feminine gender into complements, advantages and opportunities to be competitive in a labor market culturally designed for men in making decisions that concern work.

The underlying hypotheses of the research refer to the competitive abilities of women with respect to men, female and male behavior patterns; how to complement teamwork with members of both genders; Cultural learnings of gender roles: practical advice to be competitive in a world designed for men at work; power aspects to empower women in informal education; strategies to obtain political and labor power; attributes necessary for the paradigm shift; differences between power and formal authority; leaderships to empower women.

The limitations of the research refer to cultural and ethical aspects, of the paradigm that Mexicans live from their upbringing in formal and informal education, linked to the idiosyncrasy of personal development in a culture without gender equality.

\section{Theoretical framework}

The integration of Mexico into the world economy to the free trade agreement with North America, currently called T-MEC trade agreements with the United States and Canada, the economic recession that the world has experienced due to the global economic paralysis due to the COVID 2019 pandemic in recent times, it has led to capital investments being in a fragile and highly politicized economy facing a global crisis, affecting humanity regardless of gender.

At the same time, unskilled labor with low operating costs have given Hindus, Koreans and Chinese competitive advantages with the TMEC to take possession of the first places in the world in economy and labor force, far ahead of Mexico in maquila. and commercialization of goods and services with the United States, as well as others with stable economies such as Japan, England and Germany. 
This world economic recession and of our country, generates inflation, high prices for products and services, a lower per-capita level of life and therefore a high rate of galloping unemployment with a greater competitive disadvantage in the hiring of women in the market At work, culturally, preference is given to the male gender when job opportunities are scarce. It is a fact that working women are paid lower wages than men in equivalent or similar positions in the country's companies.

It is important that women have the knowledge of all these macro and micro trends, to be able to intentionally access positions of power.

First, it is necessary to differentiate power, authority and politics when exercising both political and business leadership, as well as knowing the origins and types of power over groups and practical strategies to obtain it in the cultural and social sphere. Women of today can change the paradigm of "long hair and short ideas", for that of ... big ideas and short hair "because now we do not want to recognize the actions and facts that reflect equity in thoughts, knowledge, skills and decision-making by women, a clear example is "countries led by women leaders like New Zealand. Iceland, Germany and Denmark, among others, have been recognized for initiatives that have been effective in managing the COVID crisis 2019" Quiñones L. (2020) the best management of public health decisions regarding the pandemic has given better results in fewer infected people and fewer deaths. Authentic leadership comes from the combination of power, authority, and politics. Power is the ability to influence with different factors the behavior of people and the events that take place. Authority can be given or acquired by different sources of power and gives you a status or social rank. Politics is the fact of exercising with negotiations and communication a balance between authority and power to solve problems, obtain concessions, commitments and carry out social activities. Davis, K. (2006).
The types of power are: 1, Personal power. It is based on a charismatic, informal and natural personality, people who have a magnetism / charisma and develop innate skills of assertiveness, communication and negotiation, friendly, kind, cooperative, reliable and helpful. 2. Legitimate power. It is formal, official or of social position. It is cultural and can be inherited like the princes, or by being the son (a). It may be due to job positions such as directors and senior politicians. You have to consider the power is only of the position. 3 . Power of the expert. That which is conferred by knowledge and specialization to the one who "knows". This power depends on the education, training and experiences acquired. For example, the power of a neurosurgeon, nuclear physicist, computer systems programmer, a worker with many years of experience, etc. 4. Political power. Directly related to leadership skills to work with people in groups and organizational systems. It comes from the support of the community, derived from good interpersonal relationships to obtain ideological support to influence social service actions. Robbins S. (2006).

\section{Methodology}

A qualitative, non-experimental research was carried out with the method of in-depth opinion interviews with five experts and controlled observation in three companies in the region: Chrysler, General Motors and Johnson Controls in the Ramos Arizpe Coahuila automotive complex with a representative sample for observation. Of the 3,500 workers at GM, Chrysler and Johnson Control, the female workforce is $21 \%$. All the interviewees have managerial positions with experiences of more than 20 years of seniority in decision-making positions. Interviews were conducted with a questionnaire containing questions about the description of the topics.

\section{Results}

Women have a lower rate of formal university education and receive less training than men. The jobs carried out by women are logistical, administrative, production, maintenance support and an average of $10 \%$ in heads, subdirectorates are only $3 \%$ in directions. Women workers in the industry tend to imitate men's behavior and clothing in order to unconsciously compete with them. 
The female workers are not cooperatives or collaborators among themselves, at any hierarchical level; on the contrary, they present rivalry behaviors and make work comments to disqualify each other. There are few women in managerial positions like $10 \%$, although in administrative, support or production positions the number of workers increases more. The women themselves promote gender discrimination and teach their children to be macho at home. Very few women help others in the workplace. Most of the positions they occupy are labor and non-managerial. Low-income and unemployed women tend to depend on their partners and sometimes endure abuse for child support. The complement in the positions is generally of subordination learned in cultural roles.

The power relations of the workers are currently related to the identification they have with people of power, control of information when they pertain to finances or personnel administration. They say they have to make greater efforts to obtain the same positions as their peers.

The power they have is due to their specialization or expert power and two cases to legitimate power for being shareholders or relatives of the owners of the company. Many of them express that they are not interested in making extra efforts, when the contributions are not considered important because they are women and they learned in the development of their environment that those who make decisions are men.

\section{Proposals for paradigmatic change and operating strategies}

The key to empowering women is in education, training, formal and informal training. Study and / or help other women in their development with scholarships or in-kind exchanges of skills: for example, domestic service in exchange for formal studies paid by the employer in informal services. Create a fund and / or trust sponsored by empowered women entrepreneurs and civil servants to provide scholarships and support to other women. Support from women as "coaching" of others, in sponsorship programs or to adopt a girl or an employee for their studies, to support their formal development.
Form associations and / or women's clubs (Women in power, Rotary entrepreneurs) that support women to change towards new horizons. Form associations and negotiations in universities to provide training, medical and psychological services for women by graduating students to carry out their social service and / or professional practices. Make agreements and gender research in universities. To form public cooperatives managed by women with levels of studies that allow them to lead and commercialize handicrafts and labor products made by women, without intermediaries. Informal labor market of products to sell homemade food, sewing, crafts, online, etc. Make skilled labor by empowering women in training for productive roles. Create a virtual female job bank to hire women. Empowered businesswomen and civil servants must lead by example in their conduct. Promote civil services of free childcare to help mothers to work.

Real practical recommendations for the "here and now": Take care of the image of women to each other. Use personal image to obtain advantages without exploiting it, behave with humanity and example of work. Demonstrate competitiveness in jobs, without gender quotas. Help develop tolerance and assertive integration with coworkers. Shift to a thought of power and personal worth. Carry out positive marketing between the same women, when things turn out excellent, you have to publicize them and not point out personal and / or work failures in the jobs. Change the role of suffering (that is taught in soap operas) for that of capable and with a positive mind to "engineer" to do the same and better than men at work. Ask the media to change those "suffer to deserve" roles so common in Latino culture. Request leaders, officials and directors of companies and politicians to hire women in their work projects. Work for the future with the teaching of Mexican children, so that they learn equity from the family, thus mothers encourage learning in household roles with attitudes of equity to give the same opportunities and permits to girls and boys. Take advantage of the role of mothers and educators of children and students so that they learn equitable behaviors where both in productive work and at home they have the same rights and obligations. 
Strategies to obtain political power, independent of gender and refer to social roles: Social exchange. Reciprocity and negotiation of favors or labor and / or social debts (not including sexual ones). Alliances. Two or more people come together in a common effort, unity is strength. Identification with higher authorities. People who have the privilege of being close to empowered figures such as private secretaries, deputy bosses, who have first-rate information to make decisions as representatives, they can also empower women and apply equitable behaviors. Information Control. People and / or departments that handle confidential data: finance, legal departments, etc. that they can apply regulations and standards fairly. Selective Services. People who offer personal labor services and become indispensable for bosses, with added values such as assertiveness, respect, speed, loyalty, reliability, effectiveness, specialized help, quality work, etc. Power and Status Symbols. Possessing privileged, expensive or eccentric material goods reflected at work in: office size, the number of subordinates in charge, driver, luxurious cars, air travel, belonging to a select club, etc., this way of obtaining power necessarily has have economic solvency and political power. Power Play. This occurs when a person uses formal or legitimate power to obtain advantages or gains of any kind. This form is dangerous and unworthy, because sooner or later the followers realize the "manipulation" of which they are subjected. Social networks. Join and form groups of common interest based on friendships and personal contacts via the internet as opinion "influencers" in virtual networks.

A change in culture requires a transformation of mindset from a traditional and obsolete paradigm of "safe work" with expectations of earning a living, settling and suffering a job to maintain a hard life where the important thing is to meet the objectives to give results economic, accepting any opportunity with the philosophy "of the end justifies the means" of Machiavelli, where you have to study and work hard to control, anticipate and anticipate any setback and meet the strategically planned goals in the short, medium and long term. The traditional paradigm regarding women throughout history is one of subordination, dependence, beings for procreation, physical fragility due to their size and natural constitution, people who give personal service and that extends to the workplace.
The current paradigm is changing towards a better inclusion of gender in the workplace, but it is not yet objective nor has it been detached from practices of sexual subordination, this is used to obtain women power when they do not have studies and developed skills. The current work paradigm is dynamic, flexible, sustainable with ecological perspectives, independent professionals, with innovation, planning for the future, quality, marketing and virtual communication, in search of talents and digital services, they focus on consumer needs, they are privileged purposes of giving results, efficiency, perseverance, flow, collaboration, demanding speed and constant personal and professional renewal. From an economic and political perspective, people are transforming and connecting and introjecting natural values in favor of the conservation of humanity.

\section{References}

Arias Galicia F. (2000). Editorial Trillas, Administración de Recursos Humanos.

Abbagnano N. actualizado por Fornero G, (2012). Diccionario de filosofía. Editorial Fondo de la cultura económica.

Chruden H. y Sherman A. (2001). Administración de Personal. Maximización del Potencial de Empleados. CECSA.

Hodgetts R. M. y Altman S. (2005). Comportamiento en las Organizaciones. Mc Graw-Hill. México.

Davis, K. (2006). Comportamiento Humano en el Trabajo. Editorial Mc Graw-Hill. México

Mcfarland D. E. (2002). Administración de Personal. Editorial Fondo de la Cultura Económica. México.

\author{
Mileno Foros (2020). \\ https://www.milenio.com/milenio-foros/en- \\ mexico-solo-8-de-las-empresas-estan-dirigidas- \\ por-mujeres
}

Quiñones L. (2020) NOTICIAS ONU, Mirada global de historias humanas. https://news.un.org/es/story/2020/05/1474002 
Robbins S. (2006). Comportamiento Organizacional. Editorial Mc Graw-Hill. México.

Schultz D.P. (2004). Psicología Industrial. Editorial Mc Graw-Hill. México.

Werther W.B. y Davis Keith. (2010). Administración de Recursos Humanos Editorial Mc Graw-Hill. México.

Women Now (2020) 26 agosto.

https://www.womennow.es/es/noticia/paises-

liderados-por-mujeres-onu/ 